\title{
152. 鍼による“小脳性眩暈症”の診断
}

\author{
（眼一頸筋反射の臨休的応用）
}

\author{
武山貢次（仙台市）・渡辺一男（宫城棕立冒学校）
}

I. 粕言 われわれは昭和 52 年, 第78回日耳嘼総会に扰

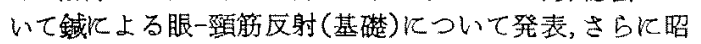
和53年，第79回日耳累総会に扮いて臨床的応用の1つと して前庭障害例について述べた。 今回は本反射を用いて 主に, 小脳性疾患について検查し，さ比奥科領域に 佶ける抆最症についても检查した。

\section{II. 実験方法}

(1) 検查方法: 先つ無刺激時の眼一丝筋反射を左右別

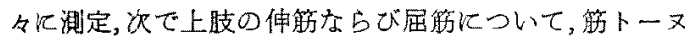
スの変化を鐵によって湘定し，最後に直荷刺激を行った

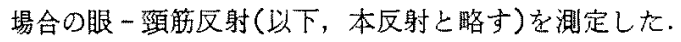

負荷の1つは視筧刺激であり，そ礼致 $3^{\circ}$ のプリズム 装用による visual suppression test (以下, V.S.) で あり，他の一つは前庭刺激として，20 cc 無水てルコー ルを注耳する万法である。なお，本反射の湘定法は仰卧 位にある患者の星状神経節ブロック点に置鐡し，㭧者に 眼を運動せしめた時（左右向，上下向，輻輳，開放）之

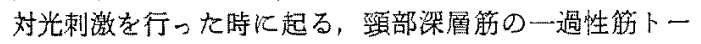
ヌスの元進を鍼を用いて测定する方法である。

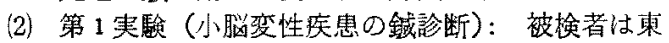

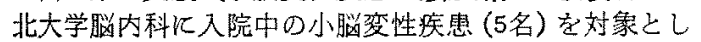
た. その結果，先つ無刺激時の㭘盖では特徴あるパター ンが得られた.すなから，眼を下向き，輻軼ならひれ対 光刺激を行った場合のみ本反射は陽性を示した。しかも， その発現するまての潜時は5〜6秒てあり（slowな反 応）またV.S.テストでは陰性孛示した（前糜疾患では。 V.S. (陽性).

また四肢筋トーヌスの検查では異常な周期性収縮を示 した。以上の特徵を利用すれば，銀に上る小脳性疾患の 診断も可能である槏沉思すれた。

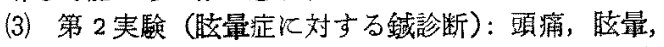
耳鳴ならびその他を主訴として来院, 検査を行った患者 総数は138名であり，艺の中瞱最を主訴とした症例は41 名であった.この41名に詨して, 先づ耳悬科領域の検查

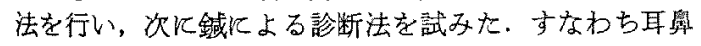
科的検查法として, 精密聴力検查, 次に前庭検㸖法老行 った. 前庭検查法としては，各種自発眼振检查，Hallpike 氏温冷水刺激法, 手廻し Cupulometrie, Goniogram $\emptyset$ 作製， E.T.T., O.K.P. テス卜の外当科で開 発した两側同時力口リ一刺激法学行った. この両耳同時 カロリ一刺激法によって, 所謂, 眼振方向優位性を末梢 性と中枢性の2つに分ける事ができた，実騟の結果，41 名中15桀すなわち $36 \%$ に前述した小脳型パターンを示 应例を認め大。

\section{III. 考 按}

（1）䠦床例の分析：鍼診断によって得られた小脳型心 ターンを示した15名について検討を行っだ結果，原因と
して椎骨動脈頜域の異常に由来主る場合が多い事が解っ

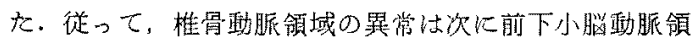
域の暴常を来し，次で前庭小脳菜江対して何等汃の機能

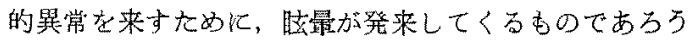

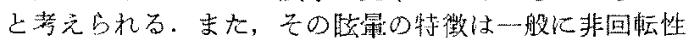
であり，フラフラ感が多く，末た一過性少行障旨をきた す場合むあり，前庭由来の胘最とは異る点が多い。ここ

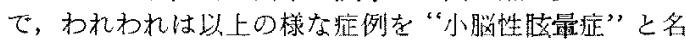
づける事とした。

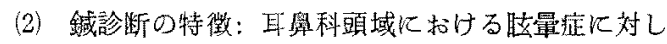
て，各種の西洋医学的アプローチを試みても，診断に困 難を感ずる場合が非常に多い，また鍼診断の結果得られ た小脱性睎掌症に対して西洋医学的アプローチを試夕て 毛，全く所見を見出す事が出来ない場合が多い．以上の

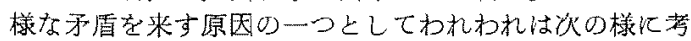
えた、すなわち，西洋医学診断の可能な筑囲は病態が未 だ機能的異常にある場合は診断が困難である場合が多 い、これに反し，本反射を利用寸る鋮診断では，嘰能的 障䇺も把握する事ができるためではないかと教えりれ t.

IV. 結 ひ

（1）今回，われわれは鍼比よる眼一頸筋反射妾利用し て小脳疾患の部断を試みた。

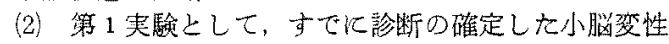
疾㭧 (5名) を㭘查した。 その結果，本疾患儿特有な反応 パターンを認めた。これを“小临型パターン”と名づけ た．彷って，以上の結果を利用すれば，鍼によって小脳 性疾患の診断も可能となってくることが判った。

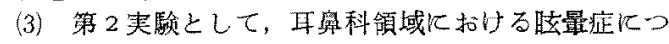
いて検查行った，先の結果，41名中15名に“小脳パ夕

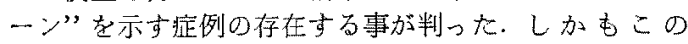

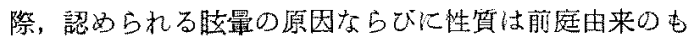
のと蛽る点が多い，そこで以上の様な淀例を“小脸性 睹最症”之名つけた。

(4) 以上の様に，病態が未だ機能的障害にある場合に

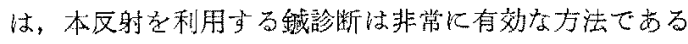
䓵吕判った。

質問 野村公寿 (東游大) 鐡では,ブロックに比就 して，星状神経節にあてるときの磪認が蜼しいと思かれ る. 何か良い力法があるか。応答 武山員次 われわ

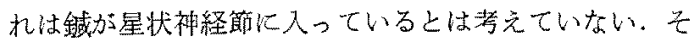
の付近の場所以機能的刺激を与交ているものと考克る。 プロカインブロックて区応の消失は確めている．貿問

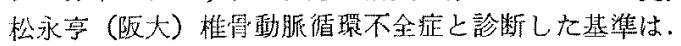

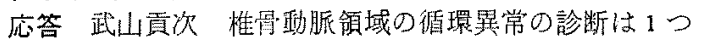
は鰂推のレントゲン，雑筸の㯖取によっている．質問者 のような器械は使用していない（B 82-1127一12591） 